Silva, J. D., Delapedra, A. T., Manoel, A. M. C., \& Cassiolato, I. H. M. (2021). Impact of Personal Values on Political Consumption: The moderating role of interpersonal influence in social media. Consumer Behavior Review, 5(3), 400-415.

DOI: https://doi.org/10.51359/2526-7884.2021.251206

ISSN: 2526-7884

Editor: Prof. Dr. Marconi Freitas da Costa

E-mail: cbr@ufpe.br
Evaluation: Double blind review

Received: July 20, 2021

Approved: September 07, 2021

\title{
IMPACT OF PERSONAL VALUES ON POLITICAL CONSUMPTION: THE MODERATING ROLE OF INTERPERSONAL INFLUENCE IN SOCIAL MEDIA
}

Impacto dos Valores Pessoais no Consumo Político: O papel moderador da influência interpessoal em mídias sociais

Juliano Domingues da Silva ${ }^{1}$

ORCID: http://orcid.org/0000-0001-7599-0617

E-mail: jdsilva2@uem.br

Ana Tereza Delapedra²

ORCID: http://orcid.org/0000-0002-1886-4849

E-mail: anadelapedra@hotmail.com

Ana Maria Campos Manoel ${ }^{1}$

ORCID: http://orcid.org/0000-0002-9374-1742

E-mail: anamariacamposmanoel@gmail.com

Isis Helena Martins Cassiolato ${ }^{1}$

ORCID: http://orcid.org/0000-0003-3036-4772

E-mail: cassiolatoisis@gmail.com

${ }^{1}$ Universidade Estadual de Maringá, Maringá, Brasil

${ }^{2}$ Fundação Getúlio Vargas, São Paulo, Brasil

\section{Abstract}

This study aims to analyze the moderating effect of interpersonal influence in social media on the relationship between personal

\section{Resumo}

O objetivo dessa pesquisa é analisar o efeito moderador da influência interpessoal em mídias sociais na relação entre valores 
values and political consumption. Through a survey of 206 respondents, the results of linear regression analysis showed that the values of self-transcendence and openness to change are positively related to political consumption, whereas self-promotion has a negative relation. The results also showed that interpersonal influence in social media has a critical moderating effect since (i) amplifies political consumption of people with selftranscendence values and (ii) increases the political consumption of people with selfpromotion values. This research expands the literature on consumer behavior by showing that personal values on political consumption depend on the individual's susceptibility to being influenced by social media.

Keywords: Political consumption; Personal value; Interpersonal influence; Social media; Consumerism. pessoais e consumo político. Por meio de uma survey realizada com 206 respondentes, os resultados da análise de regressão linear evidenciaram que os valores de autotranscendência e abertura à mudança têm relação positiva com o consumo político, enquanto a autopromoção apresenta uma relação negativa. Os resultados mostraram também que a influência interpessoal em mídias sociais exerce um efeito moderador importante para o engajamento em consumo político, uma vez que (i) amplifica a predisposição de pessoas com valores de autotranscedência em realizar consumo político e (ii) aumenta a predisposição em realizar consumo político de pessoas com valores de autopromoção. Essa pesquisa expande a literatura do comportamento consumidor por mostrar que o impacto dos valores pessoais no consumo colaborativo depende da suscetibilidade do indivíduo ser influenciado em mídias sociais.

Palavras-chave: Consumo Político; Valores pessoais; Influência interpessoal; Mídias sociais; Consumerismo.

This work is licensed under a Creative Commons Attribution 4.0 International License.

\section{INTRODUCTION}

Political consumption expresses the consideration of ethical or political reasons in the decision to buy or boycott certain products or brands, aiming at changing institutions, organizations, or social conditions (Rössel \& Schenk, 2017; Stolle, Hooghe \& Micheletti 2005). The primary forms of political consumption refer to ( $i$ ) the positive purchase (buycott) of products differentiated by specific ethical or political characteristics, such as sustainability, social justice, or corporate responsibility; (ii) the boycott of products that lack these characteristics (Rössel \& Schenk, 2017); and (iii) the perception of power that people have through consumption (Echegaray, 2012).

Political consumption concerns both the literature, managers and public agents interested in consumer behavior (Rössel \& Schenk, 2017). In this sense, in recent years, researchers have been interested in identifying determining factors that lead people to engage in political consumption (Ladhari \& Tchetgna, 2015; Barcellos, Teixeira \& Venturini, 2014; Pepper, Jackson \& Uzzell, 2009). For example, Barcellos et al. (2014) showed how personal values are related to political consumption, exposing that self-transcendence values are prevalent in consumer groups that carry out buycotts or boycotts.

Furthermore, given the virtual environment's impact on people's behavior worldwide, some studies have been dedicated to identifying how social media influence political consumption (e.g., Zúñiga, Copeland \& Bimber, 2014; Hyun \& Kim, 2015; Goh, Xin \& Jin, 2019). These studies demonstrate that social media platforms act as a catalyst for political consumption practices through the interpersonal influence between users (Bearden, Netemeyer \& Teel, 1989; Mascarenhas \& Higby, 1993, Wang, Yu \& Wei, 2012).

Although recent research has contributed to deepening the knowledge about political consumption, research flows (personal values and influence of social media) occur separately, 
neglecting that interpersonal influence in social media can motivate people with different values to carry out political consumption. The present study aims to fill this gap.

Therefore, the first objective of this research is to analyze the relationship between personal values (Schwartz, 1994; Schwartz et al., 2012) and political consumption. Personal values are widely studied as predictors of consumption (e.g., Teodoro et al., 2021, Ahmad et al., 2020). This research argues that each dimension of the personal values scale acts differently to influence political consumption. The second objective is to analyze the moderating effect of interpersonal influence in social media on the relationship between personal values and political consumption. We propose that the interpersonal influence carried out among peers in virtual social media amplifies or modifies the intention to perform political consumption, given the different personal values that predominate in the individual's characteristics.

Based on an online survey with 206 respondents, this research shows that while selftranscendence has a positive effect, self-promotion has a negative effect on political consumption, in line with Barcellos et al. (2014) and Pepper et al. (2009). Furthermore, this study advances along two new paths in the literature. First, the results demonstrate that openness to change is a set of personal values that lead to political consumption. Political consumption practices configure as innovative actions that reinforce hedonism and self-stimulation (Schwartz et al., 2012; Wang, Dou \& Zhou, 2008). Second, the results show that interpersonal influence on social media (i) amplifies the predisposition of people with self-transcendence values to perform political consumption and (ii) increases the predisposition to carry out political consumption of people with self-promoting values.

This research contributes to the political consumption literature by demonstrating that interpersonal influence on social media has an important effect on political consumption. Specifically, we show that people with self-transcendence tend to increase their engagement with political consumption. However, people with self-promoting values start to perform political consumption since political consumption influenced by peers in social media might generate status and personal success.

\section{THEORETICAL BACKGROUND AND HYPOTHESIS}

\section{Political Consumption}

Political consumption is a movement based on political consumerism, in which the consumer externalizes values and beliefs and projected them on products and the companies (Echegaray, 2012, Bossy, 2014). Bossy (2014) defines political consumption as a repertoire of actions that consumers can resort to, such as boycott, buycott, ethical investment, among others. The politicization of consumption occurs through the consumer's purchasing power, which sanctions companies with negative performance and rewards those that meet conduct expectations (Echegaray, 2012). Thus, the most common form of expression of political consumption is boycott: the attempt to achieve specific goals by encouraging individual consumers to refrain from making certain purchases in the market (Friedman, 1991). Boycott is an old phenomenon present in several contexts. However, actions involving consumption have recently expanded with the dissemination of buycott.

Buycott is an attempt to encourage buyers to choose products and services from certain companies to reward them for behavior consistent with the activists' goals (Friedman, 1991). While boycotts aim to punish companies for their mistakes, buycotts aim to reward them for good conduct (Friedman, 1991).

The political consumption actions directly impact the performance of companies and might have positive results that generate benefits for society in general, not just for individual consumers who practice political consumption. The consumers' power pressures companies, who respond to claims and change their behavior (Echegaray, 2012). Micheletti (2003) considers the act of consuming as a form of personal expression, in which the individual can externalize individual demands and values. 


\section{Personal Values}

According to Schwartz and Bilsky (1987), values are "concepts or beliefs about end states or desirable behaviors, which transcend specific situations, guide the selection and evaluation of behaviors and events and are ordered by their importance" (p. 551). Thus, personal values guide people's lives in decision making, justifying their actions and thoughts (Schwartz et al., 2012). Similarly, Schwartz and Bilsky (1987) understand personal values as criteria that guide the actions of individuals and justify them, used in the evaluation of people and events.

For Schwartz (1992), values can be distinguished through their content and structure: the content of values refers to their source of motivation, while the structure of values relates them to each other according to compatibility or contrariety. In this sense, personal values cognitively represent three types of universal human needs: (a) biological needs of the organism; (b) social interaction needs for the regulation of interpersonal relationships; (c) socio-institutional needs that aim group well-being and survival (Schwartz \& Bilsky, 1987). Ten types of motivational values are derived from these types of basic human needs understood as the motivation of personal values.

Table 1 shows each type of value; when people act on these specific values, they promote the primary motivational value type (Schwartz, 1994).

\section{Table 1}

Types of motivational values

\begin{tabular}{cl}
\hline Value type & \multicolumn{1}{c}{ Value items } \\
\hline Universalism & $\begin{array}{l}\text { Tolerance, understanding, appreciation, and protection of people and nature (social } \\
\text { justice, equality, peace, wisdom, broadmindedness, protecting the environment, unity } \\
\text { with nature, beauty). }\end{array}$ \\
Benevolence & $\begin{array}{l}\text { Preserving or enhancing the welfare of close others (helpful, forgiving, loyal, honest, } \\
\text { responsible). }\end{array}$ \\
Conformity & $\begin{array}{l}\text { Restraining urges that are likely to harm or upset others, or violate social norms or } \\
\text { expectations (self-discipline, politeness, obedience, honouring parents and elders). }\end{array}$ \\
Tradition & $\begin{array}{l}\text { Respecting, accepting, and committing to customs and ideas imposed on an individual by } \\
\text { one's culture or religion (humbleness, moderation, devotion, respect of tradition). }\end{array}$ \\
Security & $\begin{array}{l}\text { Safety and stability of self, direct relationships, and society at large (national security, } \\
\text { family security, social order, reciprocation of favours, clean). }\end{array}$ \\
Power & $\begin{array}{l}\text { Dominance or control over people and non-human resources, attaining social prestige } \\
\text { (authority, wealth, social power and recognition, preserving public image). }\end{array}$ \\
Achievement & $\begin{array}{l}\text { Personal success or competence as defined by social norms or cultural standards } \\
\text { (ambitious, influential, successful, capable). }\end{array}$ \\
Stimulation & $\begin{array}{l}\text { Pleasure, satisfying sensuous needs (pleasure, enjoying life). } \\
\text { Challenge in life, excitement, and novelty (an exciting life, a varied life, pursuing daring } \\
\text { activities). } \\
\text { Self-direction }\end{array}$ \\
& $\begin{array}{l}\text { Autonomy over one's thoughts and actions, not being controlled or influenced by others } \\
\text { (creativity, curious, independent, freedom, choosing own goals). }\end{array}$ \\
\hline
\end{tabular}

Source: Adapted from Schwartz (1994).

In addition to the content of values, it is possible to understand the structure of values (Schwartz \& Bilsky, 1987; Schwartz, 1992; Schwartz, 1994). To identify the relationship structure of values, we have to consider that the actions taken in the search for each type of value have psychological, practical, and social consequences that may be conflicting or compatible with the search for other types of values (Schwartz, 1994). From the moment people seek values, they can analyze conflicts and compatibilities between the types of these values, and thus, generate hypotheses about potential relationships between universal values can be produced (Schwartz, 1992). Schwartz (1992) proposes that values form a continuum of related motivations, constituted from the shared emphasis of underlying value types (see Figure 1).

Values with opposite motivations clearly show a contrast between them, locating in two bipolar dimensions, as shown in Figure 1. The Openness to Change-Conservation dimension distinguishes values that emphasize independent action and thinking and that favor change (selfdirection, stimulation) from those that underline self-restraint, preservation of traditional practices, 
and stability (safety, conformity, tradition) (Schwartz, 1994). The second dimension contrasts Selftranscendence and Self-promotion, dissociating values that emphasize acceptance of others as equals and concern for general well-being (universalism, benevolence) from those that emphasize the pursuit of one's success and domination of others (power, achievement) (Schwartz, 1994). According to Schwartz (1992), hedonism can express both openness to change and self-promotion, expressing the continuity of this theoretical model.

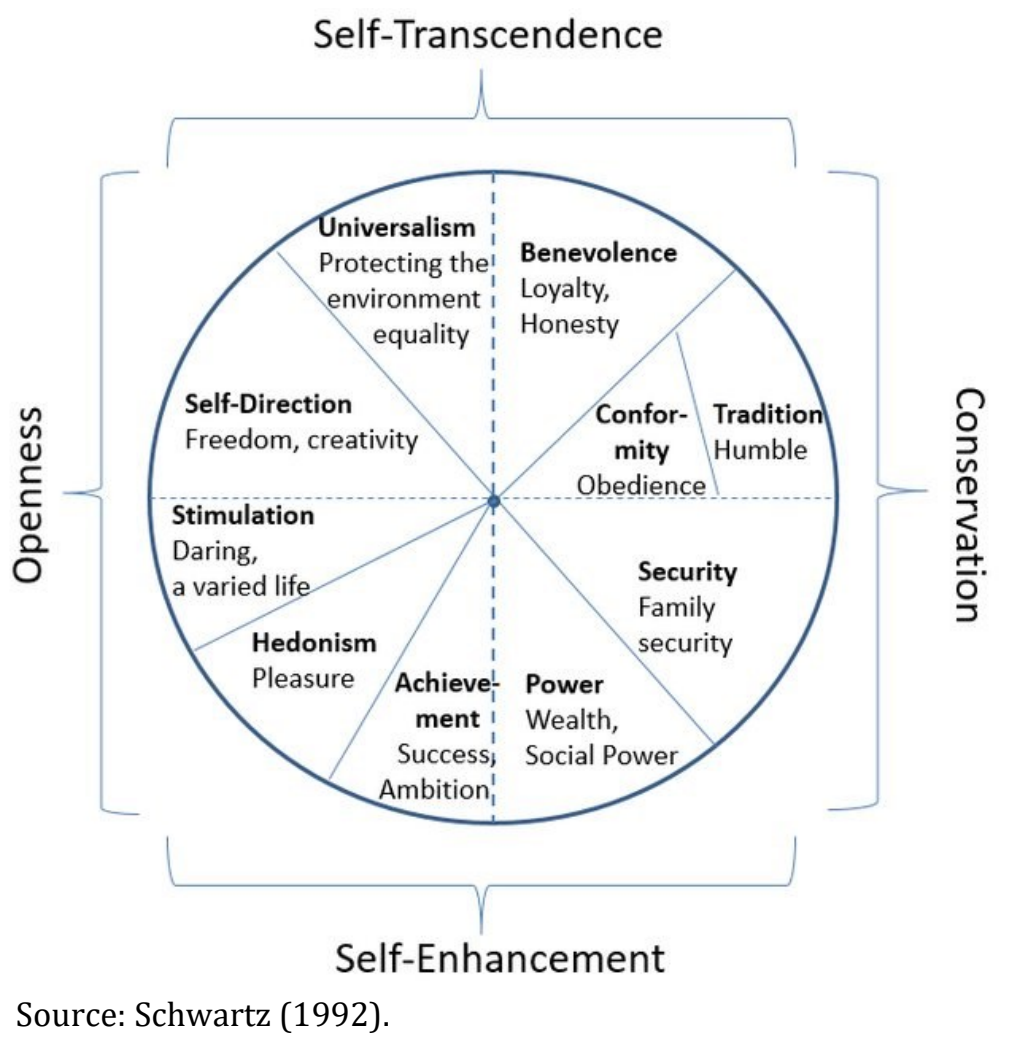

Figure 1. Schwartz' (1992) circumplex model of human values displaying four higher

Barcellos et al. (2014) analyzed the association between personal values and political consumption behavior. The authors demonstrated the central personal values found were: (1) benevolence - concern for improving the quality of life of people close to the interviewees; (2) universalism - understanding, appreciating, tolerating, and protecting the well-being of people and nature (Barcellos et al., 2014); both oriented towards self-transcendence. Given the theoretical articulation of Schwartz and based on empirical evidence from Barcellos et al. (2014), we propose the hypotheses in which personal values can be related to political consumption.

First, self-transcendence is considered to influence political consumption positively. Selftranscendence evidences the acceptance of others as equals and represents a concern with general well-being (Schwartz, 1994), which means that the self-transcendent individual considers himself/herself inserted in society and responsible for his/her well-being. Similarly, political consumption also expresses concern for society in general. According to Echegaray (2012), political consumption demonstrates consumer dissatisfaction with the final product and regarding the production process employed by the company and how these factors impact the well-being of society and the environment. Barcellos et al. (2014) point out that the dimension of self-transcendence is the most evident in the personality of political consumers. These values, universalism and benevolence, predominate in the profiles among the political consumers. Considering that self-transcendence is related to concern for general well-being, we propose the following hypothesis:

$\mathbf{H}_{1}$ : Self-transcendence positively influences political consumption. 
Second, openness to change has a positive influence on political consumption. Individuals that are open to change express values that emphasize independent actions and thoughts (Schwartz, 1994) and seek to appreciate new experiences (Raajpoot \& Sharma, 2006). Wang et al. (2008) found that the values of the openness to change dimension (self-direction and stimulation) are more related to consumer behavior towards the adoption of new products. Although the study by Wang et al. (2008) does not deal with political consumption, their findings can be applied to the current context of this research because political consumers aim to modify market and institutional practices based on the choice of products and companies that value good practices (Stolle et al., 2005). Moreover, political consumption is an attempt to differentiate from traditional consumption, transforming buying into a political act (Bossy, 2014). Political consumption might be a concept that suggests novelty, providing an innovative shopping experience that would be of interest to individuals open to change. Therefore, based on the Schwartz model and previous studies, we formalize the following hypothesis:

\section{$\mathbf{H}_{2}$ : Openness to change positively influences political consumption.}

Third, considering that the dimension of self-promotion is opposed to self-transcendence, we propose that self-promotion negatively influences political consumption. Individuals with selfpromoting values classify themselves as individualists, emphasizing the pursuit of personal success and power over other ones (Schwartz, 1994).

Pepper et al. (2009) applied Schwartz's value scale to examine how personal values can influence the behavior of socially conscious consumers. The authors found that socially conscious purchasing behaviors are positively related to universalism and benevolence but negatively related to the values of power and achievement. The results of Pepper et al. (2009) indicate that consumers' social awareness behavior has a positive association with the dimension of self-transcendence and a negative association with self-promotion.

Pepper et al.'s (2009) findings are analogous to what we proposed in this research since political consumption is similar to socially conscious consumption. The underlying argument for the negative relationship between self-promotion and political consumption is that self-promotion values are based on individual action, whereas political consumption suggests collective action (Thøgersen \& Olander, 2002; Barcellos et al., 2014). Therefore, we propose the following hypothesis:

\section{$\mathbf{H}_{3}$ : Self-promotion positively influences political consumption.}

Fourth, the conservation dimension contrasts with the openness to change dimension. Conservation values emphasize self-restraint, preservation of traditional practices, and stability (Schwartz, 1994). While conservative individuals propose the conservation of practices, political consumption aims to modify consumption practices and forms of political expression to differentiate from traditional forms of consumption (Bossy, 2014). Considering that conservation predisposes individuals to restricted attitudes that preserve compliance, the following hypothesis is formalized:

\section{$\mathbf{H}_{4}$ : Conservation negatively influences political consumption.}

\section{Interpersonal Influence in Social Media}

Hyun and Kim (2015) suggest that political consumption actions need the media's endorsement to be effective. From this, we consider that virtual social networks act as a mechanism that intensifies the interpersonal influence in the manifestations of political consumption, which can potentially increase the power and pressure of the consumers under companies.

Recuero (2009, p. 201) defines a social network "as a set of two elements: actors and their connections; (...) it is a metaphor for observing the connection patterns of a social group, based on the connections established between the various actors". Actors are the people who use the network, and the connections are the interactions that take place. Through social networks, actors can communicate (connections), sharing information with their network of friends on the internet. This exchange of 
information with relevant people allows the virtual social network to influence the behavior of its members through interpersonal influence (Abbade, Flora \& Noro, 2014).

Interpersonal influence in social media is related to susceptibility and social influence (Mascarenhas \& Higby, 1993). The authors suggest that the social influence of peers who communicate occurs in two ways: normative influence and informational influence (Bearden et al., 1989; Mascarenhas \& Higby, 1993; Wang et al., 2012). Normative influence concerns the direction of evaluations and choices that an individual exerts on another. Thus, under the normative influence, a person conforms to the norms of another person or group and modifies their attitudes and behaviors based on the expectations of their peers (Wang et al., 2012). Through this conformity with norms of influential interlocutors present in social media, a person faces conformity pressures when making purchase decisions (Wang et al., 2012).

Informational influence refers to the advice and guidance that an individual provides for another to make a consumption choice (Mascarenhas \& Higby, 1993; Bearden et al., 1989). This learning occurs because a person searches for information on social media from expert peers or by observing the behavior of influential others (Wang et al., 2012). Social media provide a fundamental channel for acquiring product information through peer-to-peer communication at a low cost or free of charge (Recuero, 2009). Given the possibility that virtual social networks impact political consumption through interpersonal influence, we propose moderation hypotheses. The effects of personal values on political consumption are amplified through interpersonal influence on social media.

First, we consider that the positive effect of self-transcendence on political consumption is amplified by the interpersonal influence in social media exerted on the individual. Self-transcendence involves the pursuit of values of universalism and benevolence, which generally require the presence of another part, whether real or imaginary and computer-mediated or not (Kahle, 1983). Thus, selftranscendent individuals tend to be more susceptible to the judgments or opinions of others (Homer \& Kahle, 1988). Based on this susceptibility of self-transcendent individuals to the judgments or opinions of others, we argue that self-transcendent people will be more willing to accept interpersonal influence in social media to engage in political consumption. Thus, we formalize the following hypothesis:

$\mathbf{H}_{5}$ : The positive effect of self-transcendence on political consumption is amplified when individuals receive interpersonal influence on social media.

Second, we consider that the positive effect of openness to change in political consumption does not change due to interpersonal influence in social media. Individuals with predominant personal values in the openness to change dimension are internally motivated and have a strong locus of internal control, with low emphasis on group interactions or the opinions of others (Madrigal \& Kahle, 1994). Thus, interactions with other people in social media have low or no influence on the predisposition of individuals open to change to engage in political consumption since interpersonal influence occurs when individuals are highly dependent on the opinions of others (Netemeyer, Bearden \& Teel, 1992). Thus, we propose the following hypothesis:

$\mathbf{H}_{6}$ : The positive effect of openness to change on political consumption is not impacted by interpersonal influence on social media.

Third, we propose that the negative effect of self-promotion on political consumption becomes positive when the individual receives interpersonal influence on social media. Individuals with selfpromoting values are concerned with acting and thinking independently and with their well-being. However, this search for well-being involves achieving status and prestige, which occurs through the demonstration of competencies (Schwartz et al., 2012). Interactions in virtual social networks are a space eminently for demonstrating competencies, resulting in the perception of achievement of status and prestige (Wang et al., 2012; Recuero, 2009). 
Individuals with self-promoting values also become susceptible to interpersonal influence on social media, as their interlocutors are fundamental for achieving status and prestige. As political consumption is also associated with the expression of individualism, in which consumers can express their personal values to society in general (Barcellos et al., 2014), we suggest that individuals with self-promotion will be willing to engage in practices of political consumption if these practices reinforce their perception of status and prestige, which should occur when these individuals receive interpersonal influence on social media. Therefore, we formalize the following hypothesis:

$\mathbf{H}_{7}$ : The negative effect of self-promotion on political consumption becomes positive when the individual receives interpersonal influence on social media.

Fourth, we propose that the negative effect of conservation values on political consumption will be positive when the individual receives interpersonal influence on social media. While conservation values emphasize self-restraint, preservation of traditional practices, and stability (Schwartz, 1994), conservative individuals have a social focus (Schwartz et al., 2012). The social focus suggests that conservative individuals tend to respect values suggested and accepted by peers who share the same beliefs. Thus, conservative individuals are also susceptible to the judgments or opinions of others, which means that they will also be susceptible to interpersonal influence in social media. It is not uncommon to notice actions carried out in social media that aim to boycott companies that violate beliefs and values considered important to conservative people (Silva \& Salgado, 2016). Therefore, we suggest that people with conservation values can engage in political consumption when they receive interpersonal influence in social media. Therefore, we propose the following hypothesis:

$\mathbf{H}_{8}$ : The negative effect of conservation on political consumption becomes positive when individuals receive interpersonal influence on social media.

\section{METHODS}

The survey was carried out with social media users. We collected data through a questionnaire, applied on Facebook social media with different groups. The sampling technique was non-probabilistic for convenience and through a snowball (Malhotra, 2012). Altogether, the data collection obtained 206 responses. The data collection instrument consisted of scales for measuring social values, political consumption, and interpersonal influence in social media.

To measure personal values, we used the adapted scale by Schwartz (1992), consisting of 22 items derived from the ten personal values described by Schwartz and divided into four dimensions: Self-transcendence, Openness to change, Self-promotion, and Conservation. We adapted the scales by Barcellos et al. (2014) and Echegaray (2012) for political consumption, which has 13 items, divided into three dimensions. The first dimension refers to the perception of power that the individual has about society and organizations; the second dimension refers to individuals' predisposition to reward actions they believe to be correct; the third dimension concerns the predisposition to punish misconduct. To measure interpersonal influence on social media, we used the scale of Abbade et al. (2014). We employed a five-point Likert scale for all scales, anchored by 1 - I totally disagree, to 5 - I totally agree (see Appendix A). Respondents also answered some control variables, namely: gender, age, education level, location, family income.

Regarding the analysis, we submitted the items of the scales to tests to assess normality, using measures of asymmetry ( $<3$ ) and kurtosis (<7), assuming the normality of the data (Marôco, 2010). Then, we conducted an exploratory factor analysis to validate the scales and their dimensions (Hair et al., 2009). The extracted factors were submitted to Cronbach's alpha reliability test (Hair et al., 2009) and convergent and discriminant validity tests (Marôco, 2010).

The exploratory factor analysis presented a grouping of items in four dimensions, as expected, with factor loading with values greater than .50 (Hair et al., 2009), Cronbach's alpha coefficient $(\alpha)$ with values greater than .70 (Hair et al., 2009), average variance extracted (AVE) greater than .50 and composite reliability (CR) greater than .80 (Marôco, 2010). The reliability, convergent validity and 
discriminant validity indices were satisfactory for the personal values scale (self-transcendence: $\alpha=$ $.74, \mathrm{AVE}=.51, \mathrm{CR}=.82$; openness to change: $\alpha=.85, \mathrm{AVE}=.55, \mathrm{CR}=0.86$; self-promotion: $\alpha=.80, \mathrm{AVE}$ $=.52, \mathrm{CR}=.84$; and conservation: $\alpha=.71, \mathrm{AVE}=.53, \mathrm{CR}=.84$ ), political consumption scale (perception of power: $\alpha=.82, \mathrm{AVE}=.57, \mathrm{CR}=.88$; Reward: $\alpha=.79, \mathrm{AVE}=.54, \mathrm{CR}=.83$; and Punishment: $\alpha=.73$, $\mathrm{AVE}=.53, \mathrm{CR}=.85)$ and interpersonal influence in social media $(\alpha=.72$; $\mathrm{AVE}=.51$; $\mathrm{CR}=.82)$.

After validating the dimensions of the scales, the latent variables were imputed from the IBM SPSS Amos v. 20 software. According to Barcellos et al. (2014), the four dimensions of social values were maintained. However, we created a latent second-order variable for political consumption and interpersonal influence in social media, composed of their respective dimensions. The relationships between latent variables were analyzed using Pearson's correlation tests and linear regression (Hair et al., 2009).

\section{DATA ANALYSIS AND DISCUSSION}

The first part of the questionnaire consisted of knowing the profile of the respondents, such as gender, age, education, location (city/state/country), and income. Most respondents are female (64.5\%). The predominant age group was between 19 and 24 years (32.3\%), followed by between 25 and 30 years (15.4\%). Data show that most of the sample has an incomplete higher education (34.9\%). Respondents' places of residence showed significant variation in the Brazilian states, but most reside in the states of Paraná (14.7\%) and São Paulo (11.2\%). Respondents' income ranged between $\mathrm{R} \$ 1,000.00$ and $\mathrm{R} \$ 50,000.00$ monthly, with the majority in the income category between $R \$ 1,000.00$ and $\mathrm{R} \$ 5,000.00$ monthly $(29.4 \%)$.

The first test performed was the calculation of bivariate correlation. In addition to the correlation coefficients, each variable's average and standard deviation values are also presented. As noted in Table 1, regarding personal values, openness to change has a positive correlation with selftranscendence $(r=.38)$ and self-promotion $(r=.22)$, but a negative correlation with conservation $(r=-$ .31). Moreover, self-transcendence is negatively correlated with self-promotion $(r=-.27)$. These results indicate that individuals with personal values focused on self-transcendence (i.e., thinking collectively) are opposed to personal values of self-promotion (i.e., thinking about themselves). Openness to change $(r=.51)$ and self-transcendence $(r=.38)$ are correlated with political consumption. It is noted that influence on social media correlates with openness to change and selfpromotion.

Table 1

Average, standard deviation, and correlation coefficient of the scales

\begin{tabular}{|c|c|c|c|c|c|c|c|c|}
\hline & Variable & $A(S D)$ & 1 & 2 & 3 & 4 & 5 & 6 \\
\hline 1 & Openness to change & $3.63(1.87)$ & 1 & & & & & \\
\hline 2 & Self-transcendence & $3.60(1.68)$ & $.38^{* *}$ & 1 & & & & \\
\hline 3 & Self-promotion & $3.37(1.77)$ & $.22^{*}$ & $-.27^{* *}$ & 1 & & & \\
\hline 4 & Conservation & 3.45 (1.99) & $-.31^{* *}$ & $.41^{* *}$ & .08 & 1 & & \\
\hline 5 & Political Consumption & $3.54(1.84)$ & $.38^{*}$ & $.41^{* *}$ & -.12 & .09 & 1 & \\
\hline 6 & $\begin{array}{l}\text { Interpersonal influence in } \\
\text { social media }\end{array}$ & $3.46(1.09)$ & $.51^{* *}$ & .17 & $.41^{* *}$ & .14 & .17 & 1 \\
\hline
\end{tabular}

Note: Average (Standard Deviation). ${ }^{* *} \mathrm{p}<.01{ }^{*} \mathrm{p}<.05$.

Source: Authors

Based on the assumption evidenced by Barcellos et al. (2014) that personal values are related to political consumption and to improve the analysis of the relationships, we performed the linear regression test (Hair et al., 2009). To analyze how the interpersonal influence in social media impacts the relationship of personal values and political consumption, we used the moderation test, as proposed by Aiken and West (1991). Table 2 shows the non-standardized coefficients and significance resulting from the models tested.

In model 1 , we notice that self-transcendence $(\beta=.32 ; p<.01)$ and openness to change $(\beta=$ $.24 ; p<.05)$ are the values that show a positive relationship with political consumption, as they have 
positive and significant coefficients, not rejecting hypothesis $\mathbf{H}_{\mathbf{1}}$ and $\mathbf{H}_{\mathbf{2}}$. These results demonstrate that values included in the dimensions of self-transcendence and openness to change are the values most considered by consumers when carrying out political consumption. The literature on personal values (Schwartz 1994, Schwartz et al., 2012) demonstrates that in the self-transcendence dimension, universalist individuals are predisposed to understand, appreciate, tolerate, and protect the well-being of all individuals and nature. Moreover, benevolence consists of preserving and improving the quality of life of the people that the individual has frequent contact with. In the openness to change dimension, people seek pleasure and gratification and are encouraged to the novelty. These values (thinking about others and seeking novelty) are positively associated with political consumption.

Table 2

Regression analysis on political consumption

\begin{tabular}{|c|c|c|c|c|}
\hline \multirow[t]{2}{*}{ Independent Variable } & \multicolumn{2}{|c|}{$\begin{array}{l}\text { Political } \\
\text { Consumption }\end{array}$} & \multicolumn{2}{|c|}{$\begin{array}{l}\text { Political } \\
\text { Consumption }\end{array}$} \\
\hline & Beta $(\beta)$ & Signif. & Beta $(\beta)$ & Signif. \\
\hline \multicolumn{5}{|l|}{ Control Variables } \\
\hline Gender & .055 & .859 & .054 & .896 \\
\hline Age & .121 & .495 & .164 & .368 \\
\hline Education & .090 & .386 & .093 & .386 \\
\hline Location & .034 & $.094^{\dagger}$ & .052 & $.011^{*}$ \\
\hline Income & .125 & .176 & .135 & .145 \\
\hline \multicolumn{5}{|l|}{ Direct effects } \\
\hline $\mathbf{H}_{\mathbf{1}}$ : Self-transcendence & .321 & $.001^{* *}$ & .326 & $.001^{* *}$ \\
\hline $\mathbf{H}_{2}$ : Openness to change & .241 & $.042^{*}$ & .263 & $.032^{*}$ \\
\hline $\mathbf{H}_{3}$ : Self-promotion & -.081 & $.056^{\dagger}$ & -.049 & $.048^{*}$ \\
\hline $\mathbf{H}_{4}$ : Conservation & .012 & .123 & .042 & .118 \\
\hline Interpersonal influence in social media & .047 & $.087^{\dagger}$ & .098 & $.077^{\dagger}$ \\
\hline \multicolumn{5}{|l|}{ Interactive effects } \\
\hline $\begin{array}{l}\text { H5: Self-transcendence x Interpersonal influence in } \\
\text { social media }\end{array}$ & & & .384 & $.001^{* *}$ \\
\hline 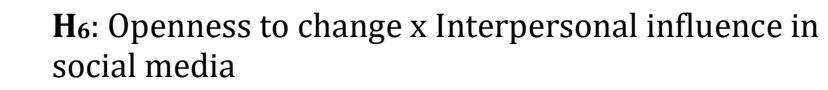 & & & .14 & .431 \\
\hline $\begin{array}{l}\text { H7: Self-promotion } x \text { Interpersonal influence in } \\
\text { social media }\end{array}$ & & & .164 & $.037^{*}$ \\
\hline $\begin{array}{l}\text { H8: Conservation } x \text { Interpersonal influence in social } \\
\text { media }\end{array}$ & & & .013 & .561 \\
\hline $\mathrm{R}^{2}$ & 19. & & 26. & \\
\hline
\end{tabular}

Note: ${ }^{* *} p<.01 ; *<<.05 ; \uparrow p<.10$. Unstandardized regression coefficients

Source: Authors.

The results of Table 2 demonstrate that, as opposed to the study by Barcellos et al. (2014) on political consumption and social values. While Barcellos et al. (2014) identified that selftranscendence is the primary value considered by the consumer, our research demonstrates that openness to change can also be considered a factor that leads to political consumption. Based on previous research (Raajpoot \& Sharma, 2006; Wang et al., 2008, Stolle et al., 2005; Bossy, 2014), we show that political consumption can be considered a novelty among consumers. As individuals open to change have values such as hedonism and stimulation, they can feel stimulated and enjoy being involved in innovative actions, such as political consumption.

Regarding the self-promotion value, the results demonstrate a negative relationship (with significance in the $90 \%$ confidence interval) with political consumption $(\beta=-.08 ; p<.10)$, not rejecting hypothesis $\mathbf{H}_{3}$. Self-promotion is supported by the values of power and achievement, in which people seek social status and prestige, and success through the demonstration of personal skills. This demonstrates that self-promotion is a more individualistic value aimed at an internal locus of control (Madrigal \& Kahle, 1994). People believe that their success or failure is the result of their skill 
and effort. Therefore, the consequences of their choices are not assigned to the other but themselves. Thus, the results of this research show that individuals with self-promotion value are not concerned with engaging in political consumption actions, as they are more concerned with their actions and choices than the actions of companies and brands, reinforcing previous findings (Barcellos et al., 2014; Pepper et al.; 2009; Thøgersen \& Olander, 2002).

In Table 2 (model 1), we noticed that conservation did not present a significant relationship with political consumption $(\beta=.01$; $n s)$, rejecting hypothesis $\mathbf{H}_{4}$. Control variables are also not influencing factors of political consumption.

In model 2, we tested the moderating role of interpersonal influence in social media on the relationship between personal values and political consumption. First, we noted that the relationship between self-transcendence and self-promotion with political consumption is impacted by interpersonal influence in social media $(\beta=.38 ; p<.01)$, not rejecting hypothesis $\mathbf{H}_{5}$. Interpersonal influence in social media amplifies the positive effect found in the relationship between selftranscendence and political consumption.

Thus, we may infer that the fact that individuals establish constant interconnections and interactions in the virtual environment makes individuals expand their network of contacts, starting to receive influence from this network and increasing their engagement in actions of political consumption (Homer \& Kahle, 1988; Bearden et al., 1989; Mascarenhas \& Higby, 1993; Wang et al., 2012). Therefore, if the individual values collective well-being (self-transcendence) and finds support to carry out these actions in the virtual environment, then the actions of political consumption increase. Figure 2a demonstrates that political consumption is high when there is a combination of a high level of transcendence and a high level of interpersonal influence in social media.

The interpersonal influence moderation test was positive for the relationship between openness to change and political consumption but not significant $(\beta=.14 ; n s)$, rejecting hypothesis $\mathbf{H}_{6}$. Regarding the self-promotion $(\beta=.16 ; p<.05)$, it is noted that the negative effect found in model 1 becomes positive and significant, not rejecting hypothesis $\mathbf{H}_{7}$. This result demonstrates that when people are only concerned with self-promotion, there is no commitment to political consumption. However, when they start to receive an interpersonal influence on social media, their behavior changes, engaging in political consumption. As suggested in the hypothesis, self-promotion is based on the values of power and achievement. Individuals seek social status, prestige, and success by demonstrating personal competencies (Schwartz et al., 2012).

From this perspective, when virtual social networks influence self-promotion, political consumption becomes a way to pursue their search for social status and prestige (Wang et al., 2012). However, suppose there is no interpersonal influence in social media. In that case, the person does not see political consumption to obtain status and prestige, demonstrating that political consumption outside the virtual environment is not interesting for people seeking self-promotion due to low visibility. This result reveals that some actions of political consumption, especially in the virtual environment, are used only to search for self-promotion.

(a)

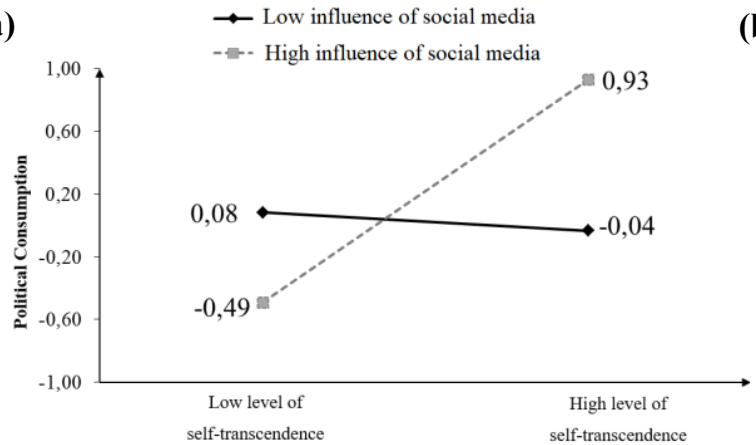

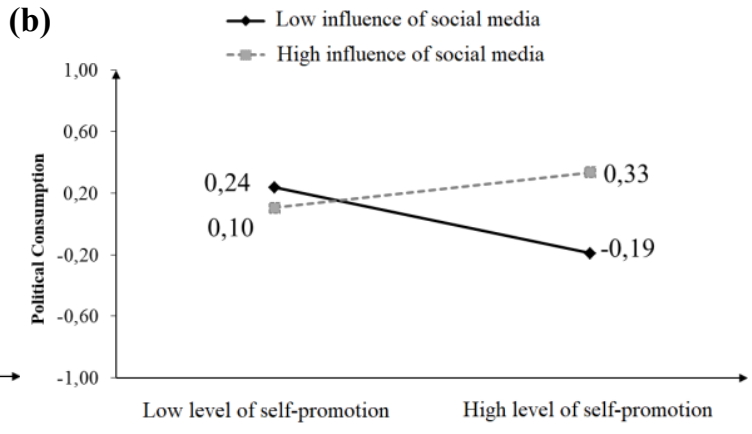

Source: Authors.

Figure 2. Moderating effect of the level of the interpersonal influence in social media on political consumption 
Figure $2 \mathrm{~b}$ shows that when there is a low interpersonal influence in virtual social networks, the relationship between self-promotion and political consumption is descending. However, when interpersonal influence in social media is high, the relationship becomes ascending, confirming the argument presented previously.

Finally, model 2 demonstrates that interpersonal influence does not have a moderating effect on the relationship between conservation values and political consumption, rejecting hypothesis $\mathbf{H}_{\mathbf{8}}$ $(\beta=.13 ; n s)$.

\section{CONCLUSIONS}

Recently, the marketing and consumer behavior literature has been concerned with exploring the meanings, causes, and effects of political consumption, both for consumers and society. This article sought to empirically understand how the interaction between political consumption, personal values, and interpersonal influence in social media. Based on Barcellos et al. (2014) and Abbade et al. (2014), we conducted empirical research to identify the consumers' personal values that influence the engagement in political consumption actions and how the interpersonal influence in virtual social networks impact this relationship.

Regarding the theoretical aspects, the results of this research corroborate pioneer studies (Barcellos et al., 2014; Pepper et al., 2009) by confirming that self-transcendence is a determining value for consumers to engage in political consumption. However, this research may advance this topic by demonstrating that the value of openness to change also leads to political consumption, but that the value of self-promotion has a negative effect. As we argued, political consumption can be seen as a novelty. Therefore, people open to change understood these actions as something innovative and fun to do. In contrast, people who seek self-promotion are not concerned with collective issues, not predisposing to engage in political consumption.

This research advances knowledge about political consumption by demonstrating that interpersonal influence in social media has an important effect on political consumption. The degree to which virtual social networks influence a person can increase engagement in political consumption. Specifically, the results show that people with self-transcendence tend to increase their engagement in political consumption. However, individuals who value self-promotion due to interpersonal influence in social media can also engage in political consumption. This activity associated with the virtual social network can improve the status and personal success.

Even seeking the methodological rigor to carry out this research, we highlight some limitations. First, this research opts for a cross-sectional approach, limiting the effect of virtual social networks on long-term political consumption, which could be evidenced in longitudinal research. The non-probabilistic sample limits precise generalizations for the entire population and analyzes stratified by groups. A second limitation refers to the engagement of political consumption. We opted to ask the respondent to indicate a predisposition to engage in this action, and based on that, to answer the scale. Thus, this study does not focus on a specific product or brand segment that considers specific themes such as environmental and/or social issues but addresses political consumption in a generalized manner. Studies that emphasize specific actions can obtain results that deepen the findings of this research. The third limitation refers to age. Surveys with a homogeneous age group, for example, with young people, could obtain more accurate results since young people have more access and are usually active in virtual social networks.

For future research, we suggest longitudinal studies to capture in more detail the relationship of consumers with more homogeneous samples, whether with a specific group of consumers or for specific types of political consumption, eliminating possible research biases. Future studies can explore the impact of specific types of virtual social networks and explore levels of ties in virtual social networks, verifying whether there is a difference in influences between the strong and weak ties of consumers. Finally, recent studies highlight the role of the personal values in order to affect B2B transactions (Manosso et al., 2021). Future studies can expand the political consumption literature by examining whether organizational buyers boycott sellers who adopt myopic positions regarding stakeholders' social and environmental well-being (e.g., Delapedra \& Silva, 2021). 


\section{References}

Abbade, E. B., Flora, A. D., \& Noro, G. B. (2014). A influência interpessoal em redes sociais virtuais e as decisões de consumo. Revista de Administração da Universidade Federal de Santa Maria, 7(2), 2656-278. http://dx.doi.org/10.5902/198346594976

Ahmad, W., Kim, W. G., Anwer, Z., \& Zhuang, W. (2020). Schwartz personal values, theory of planned behavior and environmental consciousness: How tourists' visiting intentions towards ecofriendly destinations are shaped?. Journal of Business Research, 110(March) 228-236. https://doi.org/10.1016/j.jbusres.2020.01.040

Aiken, L. S., \& West, S. G. (1991). Multiple regression: Testing and interpreting interactions. Thousand Oaks, CA, US: Sage Publications, Inc. https://psycnet.apa.org/record/1991-97932-000

Barcellos, M. D., Teixeira, C. M., \& Venturini, J. C. (2014). Personal values associated with political consumption: an exploratory study with university students in Brazil. International Journal of Consumer Studies, 38(2), 207-216. https://doi.org/10.1111/ijcs.12084

Bearden, W. O., Netemeyer, R. G., \& Teel, J. E. (1989). Measurement of consumer susceptibility to interpersonal influence. Journal of Consumer Research, 15(4), 473-481. https://doi.org/10.1086/209186

Bossy, S. (2014). The utopias of political consumerism: The search of alternatives to mass consumption. Journal of Consumer $\quad$ Culture, 14(2), 179-198. https://doi.org/10.1177/1469540514526238

Delapedra, A. T. F., \& da Silva, J. D. (2021). Business strategies under the new marketing myopia perspective. Revista Pensamento Contemporâneo em Administração, 15(1), 107-121. https://doi.org/10.12712/rpca.v15i1.48604

Echegaray, F. (2012). Votando na prateleira: a politização do consumo na América Latina. Opinião Pública, 18(1), 44-67. http://dx.doi.org/10.1590/S0104-62762012000100003

Friedman, M. (1991). Consumer boycotts: A conceptual framework and research agenda. Journal of Social Issues, 47(1), 149-168. https://doi.org/10.1111/j.1540-4560.1991.tb01817.x

Goh, T. T., Xin, Z., \& Jin, D. (2019). Habit formation in social media consumption: a case of political engagement. Behaviour \& Information Technology, 38(3), 273-288. https://doi.org/10.1080/0144929X.2018.1529197

Hair, J. F., Black, W. C., Babin, B. J., Anderson, R. E., \& Tatham, R. L. (2009). Análise multivariada de dados. Bookman Editora.

Homer, P. M., \& Kahle, L. R. (1988). A structural equation test of the value-attitude-behavior hierarchy. Journal of Personality and Social Psychology, 54(4), 638-646. http://dx.doi.org/10.1037/0022$\underline{3514.54 .4 .638}$

Hyun. D., \& Kim, J. (2015). Differential and interactive influences on political participation by different types of news activities and political conversation through social media. Computers in Human Behavior, 45, 328-334. https://doi.org/10.1016/i.chb.2014.12.031

Kahle, L.R. (1983), Social Values and Social Change: Adaptation to Life in America, New York, Praeger.

Ladhari, R., \& Tchetgna, N. M. (2015). The influence of personal values on Fair Trade $\begin{array}{llll}\text { consumption. Journal of Cleaner } & \text { Production, 87, }\end{array}$ https://doi.org/10.1016/i.jclepro.2014.10.068

Madrigal, R. (1995). Personal values, traveler personality type, and leisure travel style. Journal of Leisure Research, 27(2), 125-142. https://doi.org/10.1080/00222216.1995.11949738

Malhotra, N. K. (2012). Pesquisa de Marketing: Uma Orientação Aplicada. Bookman Editora.

Manosso, T., Silva, J., Antoni, V., \& Damacena, C. (2021). Effect of Personal Values Similarity on B2B Relationship Value. Brazilian Business Review, 18(3), 278-296. https://doi.org/10.15728/bbr.2021.18.3.3

Marôco, J.(2010). Análise de equações estruturais: Fundamentos teóricos, software \& aplicações. ReportNumber. 
Mascarenhas, O. A., \& Higby, M. A. (1993). Peer, parent, and media influences in teen apparel shopping. Journal of the Academy of Marketing Science,21(1), 53-58. https://doi.org/10.1177/0092070393211007

Micheletti, M. (2003). Why political consumerism?. In Political virtue and shopping (pp. 1-36). Palgrave Macmillan, New York. https://link.springer.com/chapter/10.1057/9781403973764 5

Netemeyer, R. G., Bearden, W. O., \& Teel, J. E. (1992). Consumer susceptibility to interpersonal influence and attributional sensitivity. Psychology \& Marketing, 9(5), 379-394. https://doi.org/10.1002/mar.4220090504

Pepper, M., Jackson, T., \& Uzzell, D. (2009). An examination of the values that motivate socially conscious and frugal consumer behaviours. International Journal of Consumer Studies, 33(2), 126-136. https://doi.org/10.1111/j.1470-6431.2009.00753.x

Raajpoot, N. A., \& Sharma, A. (2006). Perceptions of incompatibility in customer-to-customer interactions: examining individual level differences. Journal of Services Marketing, 20(5), 324332. https://doi.org/10.1108/08876040610679936

Recuero, R. (2009). Redes Sociais na Internet. Porto Alegre: Editora Meridional.

Rössel, J., \& Schenk, P. H. (2017). How political is political consumption? The case of activism for the global south and fair trade. Social Problems, 65(2), 266-284. https://doi.org/10.1093/socpro/spx022

Schwartz, S. H. (1992). Universals in the content and structure of values: theoretical advances and empirical tests in 20 countries. Advances in Experimental Social Psychology, 25(1), 1-65. https://doi.org/10.1016/S0065-2601(08)60281-6

Schwartz, S. H. (1994). Beyond individualism/collectivism: New cultural dimensions of values. In U. Kim, H. C. Triandis, Ç. Kâğitçibaşi, S.-C. Choi, \& G. Yoon (Eds.), Cross-cultural research and methodology series, Vol. 18. Individualism and collectivism: Theory, method, and applications (pp. 85-119). Thousand Oaks, CA, US: Sage Publications. https://psycnet.apa.org/record/199697151-003

Schwartz, S. H., \& Bilsky, W. (1987). Toward a universal psychological structure of human values. Journal of Personality and Social Psychology, 53(3), 550-562. https://doi.org/10.1037/0022$\underline{3514.53 .3 .550}$

Schwartz, S. H., Cieciuch, J., Vecchione, M., Davidov, E., Fischer, R., Beierlein, C., ... \& Dirilen-Gumus, 0. (2012). Refining the theory of basic individual values. Journal of Personality and Social Psychology, 103(4), 663-688. http://dx.doi.org/10.1037/a0029393

Silva, T., \& Salgado, T. B. P. (2016). Controvérsias em torno dos "Casais" de O Boticário: o acontecimento e a afetação dos públicos. Verso e Reverso, 30(73), 58-69. http://dx.doi.org/10.4013/ver.2016.30.73.06

Stolle, D., Hooghe, M., \& Micheletti, M. (2005). Politics in the supermarket: Political consumerism as a form of political participation. International Political Science Review, 26(3), 245-269. https://doi.org/10.1177/0192512105053784

Teodoro, A. J. S., Silva, M. G., Vilas Boas, L. H. B., \& Castro, A. L. O. (2021). Valores Pessoais no Consumo de Cafés em Cápsula. Consumer Behavior Review, 5(2), 288-306. https://doi.org/10.51359/2526-7884.2021.249263

Thøgersen, J., \& Ölander, F. (2002). Human values and the emergence of a sustainable consumption pattern: A panel study.Journal of Economic Psychology, 23(5), 605-630. https://doi.org/10.1016/S0167-4870(02)00120-4

Wang, G., Dou, W., \& Zhou, N. (2008). Consumption attitudes and adoption of new consumer products: a contingency approach. European Journal of Marketing, 42(1/2), 238-254. https://doi.org/10.1108/03090560810840998

Wang, X., Yu, C., \& Wei, Y. (2012). Social media peer communication and impacts on purchase intentions: A consumer socialization framework. Journal of Interactive Marketing, 26(4), 198208. https://doi.org/10.1016/i.intmar.2011.11.004

Zúñiga, H. G., Copeland, L., \& Bimber, B. (2014). Political consumerism: Civic engagement and the social $\begin{array}{llll}\text { media } & \text { connection. New Media } \quad \text { \& } \quad \text { Society, 16(3), }\end{array}$ https://doi.org/10.1177/1461444813487960 


\section{Appendix A - Items of the scale applied in the research}

\section{Personal values scale Openness to change}

A person who cares about having new ideas and being creative. He/she likes to be original. A person for whom it is important to make their own decisions about what they do. He/she likes to be free and not be dependent on others.

A person who likes surprises and is always looking for new things to do. He/she thinks it is important to do a lot of different things in life.

A person who is looking for adventure and likes to take risks. He/she wants to have an exciting life.

\section{Self-promotion}

A person for whom it is important to have a good time. He/she likes to take good care of her/himself. A person who seeks to take every opportunity to have fun. For he/she is important to do things that give him/her pleasure.

A person for whom it is important to be rich. He/she wants to have lots of money and expensive things.

A person for whom it is important that others respect him/her. He/she wants people to do what he/she says.

A person who attaches great importance to being able to show his/her abilities. He/she wants people to admire what he/she does.

A person for whom it is important for him/her to succeed. He/she likes to receive recognition from others.

\section{Self-transcendence}

A person for whom it is important to him/her to help those around her. He/she likes to look after his/her well-being.

A person for whom it is important to be loyal to friends. He/she is dedicated to the people who are close to him/her.

A person who thinks it is important that everyone in the world be treated equally. He/she believes that everyone should have the same opportunities in life.

A person for whom it is important to listen to people who are different from him/her. Even when he/she disagrees with someone, he/she still wants to understand that person.

A person who seriously believes that people should protect nature. Protecting the environment is important to him/her.

\section{Conservation}

A person who thinks he/she should always stick to the rules even when no one is watching. He/she thinks people should fulfill their obligations without contesting.

A person for whom it is important always to behave correctly. He/she avoids doing things that others say are wrong.

A person who cares about living in a place where he/she feels safe. He/she avoids anything that could put his/her security at risk.

A person for whom the Government must guarantee his/her safety against all threats. He/she wants the state to be strong so that it can defend its citizens.

A person who attaches importance to religion. He/she does everything he/she can to act on his/her beliefs.

A person for whom his/her it is important to be simple and modest. He/she tries not to draw attention to his/herself.

\section{Political Consumption Perception of power}

"Citizens can influence society through consumption." 
"The sums of small everyday actions can change society."

As a consumer, I can influence a company's behavior to make it more responsible.

The way people buy can help change the behavior of companies.

\section{Reward}

I usually learn about the social and environmental impacts of companies and services that manufacture the products I consume.

I prefer buying a product or contracting a service from a company because I consider that they comply with ethical, social, and/or environmental principles.

I reward a company that I believe is socially or environmentally responsible, buying its products and services or speaking highly of it to others.

\section{Punishment}

I punish a company that I believe is not socially or environmentally responsible by not buying its products and services or criticizing it in front of others.

I share information on social networks from companies that carry out actions and/or advertising campaigns that are in accordance with my values.

I criticize on social media the actions and/or advertising campaigns of companies that I believe are against my values.

\section{Interpersonal influence in social media}

I only buy products/brands that are positively commented on the internet (forums, blogs, and virtual social networks).

Posts from other users on the internet determine my brand loyalty.

I keep buying the same brands as they are rated positively on forums, blogs, and virtual social networks.

I never buy any new product unless I have already searched the internet about it.

When I do not understand prices and product quality, I consult opinions on the internet.

I seek to discuss my purchase plans with other users on the internet.

I read reviews and comments on the internet about products, services, and brands.

Reviews and opinions from internet users are sources of information I use when I am looking to buy something. 